\title{
PRAKTIK RAJA YOGA DALAM RANGKAIAN PEMENTASAN BARONG BRUTUK DI DESA TERUNYAN, KINTAMANI, BANGLI: STUDI TEOLOGI HINDU DALAM TERMINOLOGI KEARIFAN LOKAL
}

\author{
Oleh : \\ Putu Sabda Jayendra \\ Sekolah Tinggi Pariwisata Bali Internasional (STPBI) Denpasar \\ Email:sabda@stpbi.ac.id
}

\begin{abstract}
Raja Yoga is a method to connect one's self to the almighty God (Ida Sang Hyang Widhi Wasa) through the means of tapa, brata, yoga, semadhi. This method is conceptualized in Astangga Yoga passed down by Rsi Patanjali. Terminologically, the practice of Raja Yoga is covered in local genius existed in Terunyan village, Bangli regency. It is done by the so called Teruna (a group of teenagers) as a part of sacred procession of Barong Brutuk dance. Essentially, Raja yoga can be seen in the Makemit process for 42 days with a set of rules, prohibition, and ritual they call Tirtha Kayan Teruna. The success of the Raja Yoga according to local condition is when the teruna achieves niyasa, or a condition where the body and soul become one with God in its system, not overtaking the trance as other sacred dances do in Bali.
\end{abstract}

Keywords: Raja Yoga, Local Genius, Teruna, Barong Brutuk, Terunyan village.

\section{ABSTRAK}

Raja Yoga merupakan metode untuk menghubungkan diri dengan Tuhan (Ida Sang Hyang Widhi Wasa) melalui pelaksanaan tapa, brata, yoga, semadhi. Metode ini terkonsepkan melalui Astangga Yoga yang diajarkan oleh Rsi Patanjali. Praktik Raja Yoga dalam bingkai terminologi kearifan lokal yang khas terdapat di Desa Terunyan, Kintamani, Bangli, yang dilaksanakan oleh para Teruna (kelompok pemuda yang belum menikah) sebagai rangkaian dari persiapan pementasan tarian sakral Barong Brutuk. Praktik esensi Raja Yoga terlihat dalm proses yang disebut dengan Makemit selama maksimal 42 hari dengan berbagai aturan dan pantangan, serta salah satu ritual yang mengiringi pelaksanaannya, yakni pengambilan Tirtha Kayan Teruna. Keberhasilan pelaksanaan Raja Yoga menurut terminologi kearifan lokal Terunyan adalah apabila para Teruna berhasil menjadi niyasa, yaitu mengalami penyatuan jiwa-raga dengan dewa-dewa dalam sistem kearifan lokalnya, bukan pengambil-alihan jiwa raga (trance) seperti tari-tarian sakral lainnya di Bali pada umumnya.

Kata kunci: Raja Yoga, Kearifan Lokal, Teruna, Barong Brutuk, Desa Terunyan.

\section{PENDAHULUAN}

Aktivitas yoga merupakan suatu jalan untuk menyehatkan jasmani dan rohani dalam membentuk suatu individu manusia secara utuh. Yoga telah dikenal sebagai sistem filosofi kehidupan masyarakat India kuno (Sindhu, 2007, Stiles, 2002). Saat ini, yoga telah berkembang menjadi salah satu sistem kesehatan yang komprehensif dan menyeluruh. Teknik yoga klasik dikembangkan oleh Patanjali melalui Kitab Yoga Sutra (Stiles, 2002). Istilah yoga berasal dari kata Yuj dan Yoking (Bahasa Sansekerta) yang bermakna penyatuan secara harmonis dari yang terpisah (Sindhu, 2007; Stiles, 2002, Kinasih, 2010:2). Secara esensial, aktivitas yoga merupakan suatu metode yang ditempuh dalam rangka peningkatan kualitas diri individu secara jasmani-rohani dan fisikal-spiritual. Selain itu, implikasi yang juga diharapkan dalam pengimplementasian praktik yoga adalah efek 
psikologis, yang dalam hal ini adalah ketenangan batin atau ketentraman jiwa.

Secara teologi Hindu, aktivitas yoga merupakan suatu metode yang ditempuh untuk menghubungkan diri kepada Tuhan atau Ida Sang Hyang Widhi Wasa. Terkait dengan hal tersebut, secara umum, varian metode yoga dalam tujuan pencapaian tersebut dikelompokkan dalam konsep Catur Yoga atau Catur Marga Yoga yang terdiri dari:

1. Karma yoga yaitu jalan untuk menghubungkan diri dengan Tuhan melalui tindakan/kerja tanpa pamrih dan tanpa mementingkan diri sendiri, serta bekerja sebagai bentuk persembahan kehadapan Tuhan.

2. Bhakti yoga yaitu jalan untuk menghubungkan diri dengan Tuhan melalui sujud, hormat, cinta kasih, pelayanan, dan bhakti yang tulus ikhlas.

3. Jnana yoga yaitu jalan untuk menghubungkan diri dengan Tuhan melalui penguasaan atau memperdalam ilmu pengetahuan. Memperdalam ilmu pengetahuan tentang ketuhanan, atau ilmu pengetahuan tentang Sang Diri (Brahmawidya atau Atma Tattwa Jnana).

4. Rajayogayaitujalanuntukmenghubungkan diri dengan Tuhan melalui pelaksanaan tapa, brata, yoga, semadhi atau melalui pelaksanaan astanga yoga (Brahman, 2017:11).

Beranjak daripembagiantersebut, metodeRaja Yoga merupakan metode yang dewasa ini paling jarang dilakukan mengingat tingkat kesulitannya cukup tinggi. Hal ini disebabkan aktivitas ini melibatkan pengekangan terhadap indriyaindriya, hasrat-hasrat duniawi, serta pengendalian diri secara fisikal dan spiritual dalam mencapai penyatuan dengan Tuhan. Terlebih lagi generasi muda di era millenial yang notabene memiliki banyak tantangan dan godaan keduniawian, serta kecenderungan gejolak emosional yang cukup tinggi. Oleh sebab itu, sesungguhnya aktivitas Raja Yoga memiliki urgensi yang penting untuk diimplementasikan dalam membentuk karakter manusia yang seimbang antara jasmani dan rohani.

Praktik esensial dari metode Raja Yoga tampak dalam fenomena pementasan tarian sakral Barong Brutuk di Desa Terunyan, Kecamatan Kintamani, Kabupaten Bangli. Aktivitas yang tampak adalah adanya kegiatan berupa Makemit yang dilakukan oleh para Teruna (kelompok pemuda yang belum menikah) Desa Terunyan selama maksimal 42 hari. Makemit merupakan kegiatan berupa tinggal dan melakukan berbagai aktivitas yang berpusat di areal pura. Makemit adalah kegiatan yang dilakukan serangkaian dengan pementasan tarian sakral Barong Brutuk sebagai puncak rangkaian upacara Ngusaba Gede Kapat Lanang. Pelaksanaannya dilakukan menjelang Purnamaning Sasih Kapat Lanang yang jatuhnya setiap dua tahun sekali.

Pementasan Barong Brutuk sendiri pada hakikatnya merupakan ritual yang bertujuan untuk memohon anugerah kesuburan bagi Desa Terunyan. Pelaksanaannya bertempat di Pura Bali Desa Pancering Jagat Bali, yang merupakan pura utama Desa Terunyan. Kesuburan diharapkan tercapai apabila tarian sakral Barong Brutuk berhasil dipentaskan oleh para Teruna tanpa adanya halangan. Oleh sebab itu, sebelum menarikannya, para Teruna wajib untuk menyucikan dirinya terlebih dahulu lahir dan batin melalui proses Makemit. Tujuannya agar mampu mementaskan Barong Brutuk yang merupakan representasi dari dewa-dewa dalam terminologi lokal masyarakat Desa Terunyan.

Kegiatan Makemit secara umum di Bali hanya dipahami sebatas kegiatan tinggal dan menginap di areal pura. Namun khusus untuk para Teruna yang akan menarikan tarian sakral Barong Brutuk ini, kegiatan rutin yang harus dilakukan berupa praktik Raja Yoga dalam terminologi kelokalan Desa Terunyan. Kegiatan ini dikategorikan 
praktik Raja Yoga memuat aktivitas pengekangan diri, baik jasmani dan rohani menuju penyatuan sejati kepada Ida Sang Hyang Widhi Wasa dalam manifestasinya sebagai dewa-dewa dalam sistem kearifan lokal Desa Terunyan. Hal tersebut dilakukan melalui tapa, brata, yoga, semadhi, dengan segala aturan dan pantangan yang tidak boleh dilanggar sebagai esensi dari implementasi konsep Raja Yoga dalam terminologi lokal Desa Terunyan. Pelanggaran yang dilakukan diyakini membawa konsekuensi yang tidak diharapkan, yang secara umum berupa kegagalan tujuan dari upacara tersebut serta membawa malapetaka bagi dirinya dan desanya.

Praktik esensial dari Raja Yoga yang dibingkai dengan terminologi kearifan lokal khas Desa Terunyan ini menarik untuk diteliti. Tidak bisa dipungkiri bahwa praktik ini merupakan suatu bentuk pendidikan dan pembinaan karakter bagi generasi muda yang telah dikonsepkan oleh leluhur masyarakat Desa Terunyan dan diwariskan secara bergenerasi. Bisa dikatakan bahwa masyarakat Desa Terunyan sejak zaman dahulu telah menyadari urgensi pembinaan rohani terhadap generasi muda. Hal ini sangat penting mengingat fenomena yang dewasa ini mengindikasikan para generasi muda era millenial telah banyak mengalami degradasi etika moralitas. Semakin meningkatnya tindakan kriminalitas, asusila, dan tindakan-tindakan melawan hukum lainnya merupakan suatu indikator terhadap kurangnya aktivitas pembinaan generasi muda yang bermaterikan aktivitas pengekangan dan pengendalian diri.

Beranjak dari fenomena tersebut, sangat penting untuk dilakukan suatu penelusuran dan pengkajian yang mendalam terhadap praktikpraktik esensial dari Raja Yoga, terlebih yang dibingkai dengan terminologi kearifan lokal. Hal ini disebabkan karena kearifan lokal merupakan kultur yang mampu mengkondisikan masyarakat secara menyeluruh dalam berbagai aspek kehidupan, sehingga secara tidak langsung menawarkan solusi pencegahan terjadinya kesenjangan dan degradasi moral masyarakatnya sendiri. Namun hal tersebut juga baru akan efektif sepanjang disertai dengan pemahaman akan esensi atau makna-makna filosofis yang memadai. Dengan latar belakang tersebut, penulis memberikan judul "Praktik Raja Yoga dalam Rangkaian Pementasan Barong Brutuk oleh Para Teruna Di Desa Terunyan, Kintamani, Bangli: Studi Kajian Teologi Hindu dalam Terminologi Kearifan Lokal. Penekanan permasalahannya terletak pada pola implementasi Raja Yoga dalam Upacara Ngusaba Gede Kapat Lanang, dan korelasinya dengan Raja Yoga Patanjali.

Tujuan dilaksanakannya pengkajian ini adalah untuk mengenalkan warisan kearifan lokal budaya yang adiluhung berkenaan dengan pola-pola pembinaan generasi muda yang sesungguhnya memiliki esensi Raja Yoga yang sejati. Dengan pemahaman yang menyeluruh akan esensi dari hal tersebut, diharapkan aplikasinya dapat meningkat, baik secara kualitas maupun kuantitas, serta dilaksanakan secara berkesinambungan dari generasi ke generasi.

\section{PEMBAHASAN}

\subsection{Pola Implementasi Raja Yoga dalam Upacara Ngusaba Gede Kapat Lanang}

Sasaran dari pengimplementasi praktik Raja Yoga dalam Upacara Ngusaba Gede Kapat Lanang di Desa Terunyan adalah para Teruna atau pemudapemuda yang belum menikah. Kegiatan utama yang tampak sebagai proses implementasi dari Raja Yoga adalah proses Makemit. Rentang waktu pelaksanaan Makemit ini tergantung kesepakatan para Teruna, dengan rentang waktu maksimal selama 42 hari dan minimal 30 hari (satu bulan). Adapun peserta dari kegiatan Makemit ini adalah seluruh Teruna di Desa Terunyan. Meskipun tidak semua Teruna akan nyolahang Barong Brutuk, namun tetap saja seluruh Teruna ini diwajibkan terlibat dalam setiap rangkaian pelaksanaannya, mulai dari persiapan hingga akhir. Karena sejak 
awal persiapan prosesi ini dipandang sudah sangat sakral, maka Teruna yang nantinya tidak mendapatkan tugas nyolahang Barong Brutuk sekalipun harus ikut Makemit sebagai bagian dari proses penyucian dirinya.

Barong Brutuk merupakan tarian sakral yang melambangkan turunnya dewa-dewa Desa Terunyan dalam rangka memberikan anugerah kesuburan dan kerahayuan bagi seluruh masyarakatnya. Dalam terminologi kearifan lokal Desa Terunyan, tidak dikenal dan tidak pula disthanakan manifestasi Ida Sang Hyang Widhi Wasa yang dikenal dalam pantheon dewadewa menurut teologi Hindu pada umumnya, misalnya dalam wujud Trimurti (Dewa Brahma, Dewa Wisnu, dan Dewa Siwa). Manifestasi yang dianggap memiliki peran paling penting dan menjadi dewa tertinggi masyarakat Desa Terunyan adalah Bhatara adswdrRatu Sakti Pancering Jagat beserta permaisurinya, yaitu Ratu Ayu Pingit Dalem Dasar. Selain pasangan dewa tertinggi tersebut, terdapat pula dewa-dewa lain yang dianggap kedudukannya ada dibawah otoritas dewa tertinggi.

Barong Brutuk secara total berjumlah 21 yang merepresentasikan struktur hirarki dewa-dewa lokal dalam kehidupan religi masyarakat Terunyan. Oleh karena tarian tersebut melambangkan figur dewa yang sangat dihormati dan disakralkan masyarakat setempat, maka penarinya adalah para Teruna yang masih suci dan wajib menjalani proses penyucian lebih lanjut melalui tahapan Makemit. Adapun tahapan-tahapan dari proses Makemit yang wajib dijalankan para Teruna Desa Terunyan secara garis besar dibagi dalam tiga tahapan, yaitu tahap persiapan, tahap pelaksanaan, dan tahap akhir yang dapat diuraikan sebagai berikut.

\subsubsection{Tahap Persiapan}

Tahap persiapan merupakan segala yang dilakukan sebelum kegiatan Makemit dilakukan.
Kegiatan ini meliputi pengumpulan dan pemilihan para Teruna dan pembuatan bangsal atau tarup pakemit. Pengumpulan dan pemilihan para Teruna adalah tahapan paling pertama yang dilakukan. Kegiatan ini dilaksanakan setelah dalam rapat atau perarem prajuru desa adat telah mencapai kesepakatan bahwa Upacara Ngusaba Gede Kapat Lanang akan dilakukan. Penyarikan Desa akan berkoordinasi dengan para Kelihan Teruna untuk segera mengumpulkan dan memilih para Teruna yang dianggap layak untuk nyolahang atau mementaskan Barong Brutuk.

Para Teruna yang dipilih biasanya berada dalam rentang usia 18 - 27 tahun yang memang belum menikah. Rentangan usia tersebut dipilih karena kebanyakan laki-laki di Desa Terunyan telah menikah pada rata-rata usia 25 sampai 27 tahun dan jarang ada yang menikah melewati batas tersebut, apalagi menjadi Teruna tua (Jayendra, 2018:130). Para Teruna yang dipilih untuk nyolahang Barong Brutuk haruslah diprioritaskan yang tertua atau yang paling sulung di keluarganya, sebagaimana tradisi yang berlaku di Desa Terunyan bahwa yang disebut anggota Sekaa Teruna di Desa Terunyan adalah anak laki-laki yang tertua di keluarganya. Dengan kata lain, jika ada dalam sebuah keluarga memiliki lebih dari satu orang anak laki-laki, maka yang diperbolehkan untuk menarikan Barong Brutuk adalah anak laki-laki yang paling tua. Terkecuali apabila anak laki-laki yang tertua tersebut telah menikah, barulah haknya jatuh kepada anak laki-laki nomor dua, dan begitu pula seterusnya, sesuai dengan Kuna Dresta yang berlaku di Desa Terunyan.

Dalam proses pemilihan para Teruna tersebut, ada sebuah peraturan yang cukup keras bahwa meskipun secara fakta mereka belum menikah, dituntut pula mereka yang terpilih untuk mengakui secara jujur apakah selama hidupnya pernah berhubungan secara seksual dengan lawan jenis atau belum. Apabila belum, maka akan diijinkan untuk tetap menjadi penari Barong Brutuk dan mengikuti segala prosesinya. Namun 
apabila sudah, maka dituntut kerelaannya untuk mengundurkan diri dan tidak diperbolehkan lagi untuk menarikannya. Dalam hal ini kejujuran dari setiap Teruna diperlukan. Apabila diantara para Teruna tersebut ada yang berbohong dengan menyatakan dirinya belum pernah melakukan hubungan seksual pranikah, namun pada kenyataannya sudah pernah melakukannya, maka pada saat mengenakan kostum dan tapel suci Bhatara Brutuk tersebut, Teruna yang bersangkutan akan merasakan sangat panas dan tidak tahan sehingga membuka kostumnya kembali, atau ada pula yang merasakan lemas, tidak bertenaga sehingga terjatuh dan tidak mampu menari.

Berdasarkan hal tersebut, dapat disimpulkan bahwa kesucian para Teruna sebagai penarinya merupakan persyaratan yang mutlak dan diutamakan. Persyaratan tersebut tidak tertulis, namun merupakan logika berdasarkan Tattwa dan Susila dari keyakinan masyarakat Desa Terunyan akan hakikat Siwam (kesucian). Tidak saja kesucian badan atau fisik atau jasmani, melainkan juga kesucian pikiran dan batin yang dilihat melalui kejujuran. Dengan modal kesucian tersebut, para Teruna dianggap layak nyolahang Barong Brutuk yang merupakan perwujudan Bhatara tersebut dan mensthanakan kekuatan-Nya pada dirinya. Seluruh anggota yang tergabung dalam Sekaa Teruna diwajibkan ikut serta dalam prosesinya Makemit tersebut, meskipun tidak semua akan kebagian nyolahang Barong Brutuk. Selain itu, hal ini juga dimaksudkan sebagai langkah antisipatif apabila ada salah seorang atau beberapa orang Teruna yang awalnya telah ditunjuk sebagai penari Barong Brutuk ternyata mengalami sesuatu dan lain hal yang menyebabkannya tidak jadi menari.

Para Teruna mengawali kegiatan Makemit ini dengan pembuatan bangunan tarup atau dalam bahasa Bali disebut bangsal. Bangsal ini disebut bangsal pakemit yang didirikan di areal Penaleman Jeroan yang merupakan areal tersuci dari Pura Bali Desa Pancering Jagat Bali. Bangunan ini didirikan di sebelah Barat dari bangunan Meru tempat bersthananya Bhatara Ratu Sakti Pancering Jagat. Bangsal pakemit tersebut dibuat dengan rangka bambu yang nantinya diberi dinding dari anyaman bambu dan daun kelapa yang dalam bahasa Bali disebut kelangsah. Untuk atapnya dipergunakan daun ilalang kering, atau tanaman rumputrumputan kering yang di Terunyan disebut rumput blu, yakni sebangsa andropogon, yang mirip dengan tanaman serai namun tidak wangi. Tinggi tanaman ini bisa mencapai tiga meter (Danandjaja, 1980:32). Nantinya segala aktivitas berupa tidur, makan, dan berganti pakaian dilakukan di bangsal pakemit tersebut.

\subsubsection{Tahap Pelaksanaan}

Kegiatan ini dilaksanakan minimal 30 hari atau maksimal 42 hari sebelum menarikan Barong Brutuk yang jatuh tiga hari setelah hari Purnama Kapat. Selamakegiatan Makemitberlangsung, para Teruna tidak diperbolehkan meninggalkan areal pura, kecuali untuk mandi yang harus dilakukan secara bersama-sama di tepi Danau Batur. Secara umum, tujuan dari Makemit adalah menjadikan diri para Teruna tersebut suci lahir batin sehingga mampu menjadi niyasa. Istilah niyasa berarti melukiskan, menggambarkan (formula, suci, tulisan mistik/Tim Penyusun, 2006:65). Niyasa dalam pemahaman masyarakat Terunyan adalah peningkatan kesucian diri melalui formulasi dari aspek lahir maupun batin dengan tujuan agar layak menjadikan diri sendiri sebagai simbol yang melukiskan atau menggambarkan dewa tertinggi masyarakat Terunyan beserta permaisuri dan para pengiringnya. Dengan demikian, saat menarikan Barong Brutuk, jiwa dan raga para Teruna diharapkan akan mengalami penyatuan dengan dewa-dewa yang diperankan.

Praktik Raja Yoga dalam aktivitas Makemit dimulai dengan pengekangan diri terhadap hasrat jasmaniah dan godaan-godaan duniawi. Untuk mencapai tujuan tersebut, terdapat sejumlah aturan dan pantangan yang wajib ditaati. Aturan tersebut antara lain senantiasa berpikir, berkata, dan 
berbuat yang baik dan benar, serta melaksanakan kegiatan pengabdian di areal pura. Bentuk pengabdian yang dilakukan antara lain ngayah mareresik (membersihkan areal pura) secara rutin, menyiapkan berbagai sarana keperluan pementasan Barong Brutuk, dan melaksanakan berbagai persembahyangan rutin dan beberapa ritual yang dilangsungkan selama masa Makemit.

Pantanganyangwajibditaatiadalahberpantang diri untuk bersenang-senang (menikmati hiburan) berpantang diri untuk berpikiran negatif, berkatakata kasar ataupun kotor, serta berbuat hal-hal yang bertentangan dengan adat kesusilaan. Salah satu pantangan yang diyakini dapat berakibat paling fatal jika dilanggar adalah berhubungan dengan lawan jenis. Bagi para Teruna, saat berlangsungnya Makemit dilarang berbicara, bertegur sapa, apalagi sampai menggoda atau bahkan kontak secara fisik. Sebagaimana telah dikemukakan di awal, apabila sampai dilanggar, maka diyakini akan mengakibatkan kegagalan dalam nyolahang Barong Brutuk, seperti perasaan lemas saat akan menari, panas saat menggunakan tapel Barong Brutuk, atau bahkan pingsan. Apabila hal ini diketahui, langkah untuk mengantisipasi hal tersebut adalah dengan berpedoman pada awigawig di Desa Terunyan dan kesepakatan diantara para Teruna, yakni langsung dikeluarkan dari segala keterlibatannya dalam proses Makemit, dan haknya menjadi penari Barong Brutuk akan dicabut (Jayendra, 2018:149).

Secara logika, adanya kontak dengan lawan jenis berpotensi menimbulkan hasrat atau pikiran-pikiran yang tidak baik, sehingga dapat mengacaukan tujuan dari proses Makemit. Dalam konsep Hindu, penjelasan mengenai hal ini ditemukan dalam kitab Manawadharmasastra sloka 357 sebagai berikut:

\footnotetext{
Upacārakriyā kelih

Sparśo bhūsana vāsașān

Saha khațvāsanañ caiva

Sarvam samgrahanam smrtam.
}

Terjemahannya:

Memberi pemberian kepada seorang wanita, bergurau dengannya, memegang pakaiannya dan hiasannya, duduk di tempat tidur dengannya, semua perbuatan ini dianggap perbuatan zina (Pudja dan Sudharta, 2004:423).

Seluruh kewajiban dan pantangan tersebut bertujuan menumbuhkan sifat-sifat kedewataan dalam diri setiap Teruna dan menghilangkan sifat keraksasaan. Konsep ini sesuai dengan pernyataan dalam sloka Bhagawadgita XVI. 2, 3, dan 4 sebagai berikut.

Ahimisā satyam akrodhas tyāgah śāntir
apaiśunam,
dayā bhūteșw aloluptwaì mārdawaì hrīr
acāpalam.
Terjemahannya:

Tanpa kekerasan, kebenaran, bebas dari kemarahan, tanpa pamrih, tenang, benci dalam mencari kesalahan, welas asih terhadap makhluk hidup, bebas dari kelobaan, sopan, kerendahan hati, dan kemantapan (Maswinara, 1997:450).

Tejah kșamā dhritih śaucam adroho nā 'timānitā, bhawanti sampadaì daiwìm abhijātasya bhārata.

Terjemahannya:

Berani, pemaaf, teguh, murni, bebas dari kedengkian dan kesombongan, yang semuanya ini, wahai Bharata (Arjuna) merupakan anugerah pada mereka yang lahir dengan sifat-sifat dewata (Maswinara, 1997:450-451).

Dambho darpo 'bhimānaś ca krodhah pārusyam ewa ca,

ajñānaṁ cābhijātasya pārtha sampada, āsurīm.

Terjemahannya:

Berlagak, angkuh, membanggakan diri, marah, dan juga kasar serta bodoh, semuanya ini wahai Partha (Arjuna) adalah sifat-sifat mereka yang lahir dengan kecenderungan raksasa (Maswinara, 1997:451). 
Melihat keterkaitannya dengan uraian sloka di atas, sifat-sifat keraksasaan patut ditinggalkan dan sifat-sifat kedewataan wajib dimunculkan oleh para Teruna. Tujuannya agar dalam mementaskan Barong Brutuk memiliki kelayakan dari aspek kesucian lahir batinnya, karena Barong Brutuk juga merupakan gambaran dari pada dewa-dewa dalam keyakinan lokal masyarakat Desa Terunyan.

Hal lain yang wajib diperhatikan dalam prosesi ini adalah para Teruna wajib menyiapkan sendiri segala macam kebutuhan makannya, dalam artian memasak sendiri dan hanya boleh mengolah bahan makanan yang disediakan para tokoh adat dan agama setempat. Tidak diperbolehkan membawa makanan sendiri-sendiri dari luar pura, dan juga melakukan pembunuhan, misalnya memotong ayam atau binatang lain sendiri untuk dijadikan makanan. Dengan kata lain, para Teruna harus menerima apa saja sebatas yang disediakan dan mengolah, serta memakannya bersama-sama atas dasar kemandirian dan asas kesetaraan.

Kewajiban ini harus dipegang teguh dan dilaksanakan tanpa boleh mengeluh. Aktivitas ini merupakan suatu bentuk pengekangan diri terhadap segala godaan yang sifatnya badaniah (jasmani). Semua aktivitas yang dilakukan murni tertuju sebagai pengabdian yang tulus ikhlas untuk Tuhan. Pengekangan jasmani merupakan tahap awal upaya penyucian diri dalam proses pencapaian kesadaran dan penyatuan sejati sebagai esensi dari yoga. Relevansi hal ini dapat dilihat dalam Bhagawadgita IX. 27 yang menyatakan bahwa:

Yat karosi yad asnasi

Yaj juhosi dadasi yat

Yat tapasyasi kaunteya

Tat kurusa madarpanam.

Terjemahannya:

Apapun yang engkau lakukan, apapun yang engkau makan, apapun yang engkau persembahkan, apapun yang engkau dermakan, laku tapa apapun yang engkau lakukan, lakukanlah O Putra Kunti, sebagai persembahan kepada-Ku (Radhakrishnan, 2009:303).

Tahapan berikut dari praktik esensi Raja Yoga yang dilakukan selain pengekangan yang berorientasi pada jasmaniah adalah pemusatan pikiran (rohaniah). Upaya ini ditempuh melalui rutinitas pelaksanaan tapa, brata, yoga, dan samadhi. Dalam terminologi kearifan lokal Terunyan, praktik ini dilakukan melalui ritualritual yang mengiringi pelaksanaan Makemit yang diantaranya yang paling nampak jelas adalah persembahyangan rutin yang wajib dilaksanakan setiap hari, serta tampak pula dalam ritual pencarian Tirtha Kayan Teruna. Tirtha Kayan Teruna merupakan air suci yang nantinya dipergunakan untuk membersihkan tapel-tapel (topeng) Barong Brutuk.

Mencari Tirtha Kayan Teruna dilakukan tiga hari sebelum jatuhnya Purnama Kapat. Beberapa Teruna akan dipilih untuk ditugaskan untuk mencari Tirtha Kayan Teruna yang diperoleh pada sebuah mata air yang juga disebut Kayan Teruna. Letak mata air Kayan Teruna tersebut di areal Pura Prasuci di kaki Bukit Abang, arah Kaja dari areal Pura Bali Desa Pancering Jagat Bali. Para Teruna yang berangkat ke mata air Kayan Teruna pun diwajibkan berjalan kaki dengan mendaki Bukit Abang. Mereka tidak diperbolehkan berkata-kata terlalu keras, bahkan dianjurkan berbisik-bisik saja jika dirasa perlu berkomunikasi. Hal ini dilakukan agar membiasakan diri untuk tidak bergunjing, membicarakan hal-hal yang tidak patut.

Jayendra (2018:167) dalam penelitiannya mengenai "Sasolahan Barong Brutuk di Desa Terunyan, Kecamatan Kintamani, Kabupaten Bangli: Suatu Kajian Etnopedagogik" menyatakan bahwa kelompok Teruna yang mencari Tirtha Kayan Teruna harus melakukan kegiatannya dalam keadaan tanpa busana sedikitpun, dalam arti benarbenar dalam kondisi telanjang. Sesampainya di depan Pura Prasuci, para Teruna dalam kelompok tersebut seluruhnya harus melepaskan seluruh 
pakaian yang dikenakannya sebelum menaiki tebing tempat mata air Tirtha Kayan Teruna tersebut. Hal ini karena dalam rangkaian prosesi tersebut, para Teruna diwajibkan suci lahir batin dan tidak boleh tercemar oleh benda-benda duniawi. Tujuan dari melepas pakaian tersebut karena seluruh Teruna yang datang ke tempat mata air tersebut harus betul-betul berserah diri kepada Ida Bhatara. Hal ini adalah simbol bahwa untuk memperoleh anugerah kesucian secara batin, harus dilakukan dalam keadaan suci secara lahir, dan betul-betul berpasrah diri, tanpa boleh membawa apa-apa dan tanpa terikat oleh apapun.

Lebih jauh, Jayendra (2018:168) menyatakan bahwa

"Hal inilah yang menyebabkan kelompok Teruna yang mencari Tirtha Kayan Teruna sama sekali tidak boleh diikuti oleh orang lain yang tidak menjadi bagian dari kegiatan tersebut. Bahkan untuk sekedar mengambil dokumentasi juga dilarang, karena dianggap dapat mengacaukan konsentrasi para Teruna yang sedang melaksanakan prosesi yang penuh dengan nuansa kesakralan tersebut".

Adanya fenomena tersebut melambangkan proses pendakian spiritual yang panjang dan penuh tantangan. Dalam rangka mencapai kesucian lahirbatin, segala ikatan dan kemelekatan dengan halhal yang bersifat keduniawian harus ditanggalkan. Dalam mencapai niyasa atau penyatuan antara jiwa dan raga para Teruna dengan para dewa yang nantinya akan bersama-sama nyolahang Barong Brutuk, maka jiwa dan raga dibersihkan, segala hasrat duniawi ditanggalkan, serta berpasrah diri dalam menghadap Beliau untuk memperoleh kesucian dan kesadaran sejati. Relevansi hal ini dengan teologi Hindu dapat dijumpai dalam mantram Yajurveda XIX.30 sebagai berikut.

\section{Pratena dikșām āpnoti \\ dikșāya āpnoti dakșinām \\ dakșinā śraddhām āpnoti \\ śraddhāya satyam āpyate.}

Terjemahannya:

Melalui pengabdian kita memperoleh kesucian, dengan kesucian kita mendapat kemuliaan. Dengan kemuliaan kita mendapat kehormatan, dan dengan kehormatan kita peroleh kebenaran (Titib, 1996:251).

Terkait dengan pemahaman mantram tersebut, prosesi ini sesungguhnya melambangkan pencapaian kesucian melalui kelepasan dari kemelekatan indriya dan duniawi. Para Teruna melaksanakan kegiatan tersebut tanpa perasaan canggung atau malu, karena sudah tidak lagi memikirkan tentang badan jasmani. Segala pikiran terkonsentrasi pada satu titik, yakni esensi sejati dari Ida Sang Hyang Widhi Wasa. Melalui aktivitas ritual yang tulus ikhlas disertai dengan konsentrasi yang mantap, diharapkan secara bertahap akan menemukan kebenaran yang hakiki berkenaan dengan eksistensi dan segala sifat Beliau.

\subsubsection{Tahap Akhir}

Tahapan akhir dari praktik Raja Yoga dalam rangkaian pementasan tarian sakral Barong Brutuk adalah nyolahang atau tahap menarikan. Tahapan ini boleh dikatakan sebagai indikator keberhasilan pencapaian dalam proses Makemit yang telah dilakukan. Sebagai contoh, adanya cerita masyarakat setempat secara turun-temurun yang diyakini sekali kebenarannya bahwa apabila ada Teruna yang pernah melanggar pantangan namun tidak diketahui, maka akan ada tiga hal yang bisa terjadi. Pertama, saat memakai tapel Brutuk akan merasakan panas yang sangat kuat, sehingga Teruna tersebut tidak tahan dan segera melepas tapel-nya. Kedua, akan lemas tiba-tiba, bahkan pingsan saat baru akan mulai masolah. Ketiga, akan selalu merasa ingin buang air kecil, maupun buang air besar saat akan masolah (Jayendra, 2018:311).

Terkait pernyataan tersebut, Danandjaja (1980:394) menyatakan bahwa keyakinan tersebut sudah ada dan pernah terjadi di masa lampau. 
Jika para Teruna berani melanggar larangan seperti bersentuhan dengan wanita, maka akan mengalami hal-hal yang tidak enak, antara lain berupa perasaan lemas sehingga dapat mengalami kecelakaan seperti jatuh sampai luka, atau ingin membuang air besar atau kecil yang akan sangat merepotkan sekali setelah mengenakan kostum yang banyak ikatannya itu. Pandangan masyarakat terhadap hal ini adalah para dewa tidak berkenan menyatu (niyasa) jiwa raganya dengan Teruna yang sudah tidak suci lagi akibat melanggar pantangan-pantangan yang diberlakukan. Hal ini sesuai dengan teks Svetasvatara Upanisad I.13 yang menyatakan bahwa:

Laghutvam ārogyam alolupatvam varnaprasādam svara-saușthavam ca, gandhaś śubho mūtra-purīsam alpaì yoga-pravrttim prathamām vadanti.

\section{Terjemahannya:}

Perasaan ringan, perasaan sehat, ketegaran, kemantapan, perkataan yang menyenangkan, bau badan yang enak, buang kotoran sedikit inilah mereka katakan sebagai hasil pertama dari yoga (Radhakrishnan, 2008:567).

Perlu diketahui bahwa para Teruna yang menarikan Barong Brutuk tidak dalam keadaan karauhan atau mengalami trance, dalam artian melakukan aktivitas tersebut secara sadar. Namun perubahan yang terjadi dan sangat dirasakan adalah kekuatan fisik yang menjadi berlipat ganda, sehingga sangat kuat menari dalam durasi yang sangat panjang, yakni mulai pukul 11.30 Wita sampai dengan sore hari kira-kira pukul 17.00 Wita. Dalam koreografi tariannya yang hanya terdiri dari berlari dan melecut-lecutkan cambuk, kaki-kaki telanjang yang berpijak di atas medan tanah yang berisi banyak batu kerikil juga tidak dirasakan, apalagi sampai merasakan sakit. Bahkan juga tidak mengakibatkan kaki menjadi terluka sama sekali. Hal ini diungkap dalam penelitian Jayendra (2018:184) yang mengutip pernyataan dari salah seorang informan yang sekaligus sebagai penari Barong Brutuk yang menyatakan bahwa:

"Pada saat beraksi mengejar-ngejar dan melecut-
lecutkan cambuk ke arah penonton, kami sama
sekali tidak merasakan sakit, meskipun kaki
kami terkena batu-batu kerikil yang adakalanya
cukup tajam. Kami bahkan tidak mengalami
luka. Tenaga terasa berlipat ganda. Kami tidak
kesurupan, sebab menarikan tersebut dalam
kondisi yang sangat sadar sepenuhnya, hanya
saja tenaga fisik menjadi luar biasa besar".

Fenomena ini diyakini oleh para penari Barong Brutuk bahwa dirinya dimasuki kekuatan suci para dewa. Berbeda halnya dengan menarikan beberapa jenis tari-tarian Bali yang bersifat sakral atau wali lainnya, seperti misalnya Tari Sanghyang yang penarinya merasakan kesurupan atau trance. Yang dirasakan adalah bertambahnya kekuatan fisik dan emosi yang berbeda dari kondisi biasanya.

Hal ini mengindikasikan bahwa yang terjadi pada para Teruna penari Barong Brutuk tersebut adalah penyatuan jiwa dan raganya dengan spirit kekuatan suci Ida Sang Hyang Widhi Wasa, bukan pengambil-alihan badan tanpa disadari sebagaimana fenomena kesurupan yang kerap terjadi pada tari-tarian sakral lainnya. Dalam terminologi kearifan lokal Desa Terunyan, hal inilah yang disebut sebagai niyasa.

Keberhasilan dalam nyolahang Barong Brutuk diyakini akan membawa anugerah kesuburan sebagai ideologi utama dari Barong Brutuk. Di samping itu, diyakini oleh masyarakat bahwa desanya akan terbebas dari malapetaka seperti wabah penyakit, kekeringan, dan kelaparan akibat kurangnya kesuburan tanah-tanah pertanian dan ketersediaan ikan-ikan di Danau Batur. Oleh sebab itu, dapat dikatakan bahwa tanggung jawab para Teruna Desa Terunyan sangat berat, karena kemakmuran desanya ditentukan oleh keberhasilan praktik-praktik yoga yang dilakukan. 


\subsection{Relevansi Praktik Raja Yoga Dalam Terminologi Lokal Desa Terunyan Dengan Konsep Raja Yoga Patanjali.}

Praktik Raja Yoga dalam terminologi lokal Desa Terunyan tersebut apabila dikorelasikan dalam konsep Raja Yoga dalam ajaran Rsi Patanjali, maka sesungguhnya esensi dari praktik tersebut sangat relevan. Relevansinya dapat dipahami apabila dikomparasikan dengan mengacu pada konsep Astangga Yoga. Menurut Rsi Patanjali seorang yogi mesti melaksanakan pendisplinan diri dengan melaksanakan yoga (Raja Yoga) melalui pelaksanaan Astangga Yoga atau delapan bagian dari yoga. Dalam yoga sutra Rsi Patanjali (II.29) disebutkan bahwa:

Yama niyamasana pranayama

pratyahara dharana dhyana samadha yo

'stw angani (Yoga Sutra, II. 29).

Terjemahannya:

Astangga Yoga terdiri dari: yama, niyama, asana, pranayama, pratyahara, dharana, dhyana dan samadhi (Brahman, 2017:16).

Merujuk pada sutra Rsi Patanjali tersebut, maka pembagian dari Astangga Yoga secara bertahap adalah; 1) Yama, 2) Niyama, 3) Asana, 4) Pranayama, 4) Pratyahara, 5) Dharana, 6) Dhyana, dan 6) Samadhi. Konsep Astangga Yoga tersebut merupakan pedoman yang sifatnya prinsip dan esensial dalam pelaksanaan Raja Yoga. Apabila dikorelasikan dalam praktik Raja Yoga dalam terminologi lokal Desa Terunyan sebagaimana yang telah diuraikan di atas, maka dapat dispesifikasikan sebagai berikut.

\subsubsection{Yama}

Yama merupakan pengendalian diri tahap pertama dengan arah orientasi pengendaliannya adalah badan jasmani. Ajaran Yama merupakan ajaran pengendalian diri tahap awal, yang berorientasi pada pembentukan perilaku secara nyata. Yama terdiri dari:

1. Ahimsa, yang artinya tidak membunuh atau menyakiti. Dalam proses penyucian diri serangkaian persiapan nyolahang tarian sakral Barong Brutuk, para Teruna diwajibkan tidak berpikiran tidak patut, berkata-kata yang bisa menyakiti orang lain, serta berperilaku yang baik, termasuk boleh membunuh binatang di areal pura.

2. Satya, yang artinya jujur dan setia, serta memegang teguh kebenaran. Konsep ini direfleksikan dalam perilaku kejujuran para Teruna untuk teguh dalam menjalankan aturan-aturan dan pantangan Makemit dengan penuh tanggung jawab.

3. Asteya, yang artinya tidak mencuri, merampok, atau tidak menginginkan sesuatu yang bukan hak milik. Konsep ini direfleksikan melalui aturan dan pantangan yang ada karena para Teruna memang dilarang untuk berbuat yang tidak baik. Hal ini didasari keyakinan bahwa segala tingkah lakunya senantiasa diawasi oleh Bhatara Ratu Sakti Pancering Jagat yang bersthana di pura tersebut.

4. Brahmacarya, yang artinya mengendalikan nafsu seksual. Hal ini direfleksikan melalui pantangan berinteraksi, bersentuhan, bahkan menggoda lawan jenis.

5. Aparigraha, yaitu hidup sederhana, yang direfleksikan melalui kewajiban untuk mandiri dan hanya makan makanan yang disediakan, serta asas kesetaraan dan kebersamaan dalam prosesi Makemit.

\subsubsection{Niyama}

Niyama merupakan konsep pengendalian diri tahap lanjut yang berorientasi pada pembentukan rohani atau mental spiritual untuk mencapai kesucian batin. Niyama terdiri dari:

1. Sauca, yang artinya suci lahir batin. Konsep ini direfleksikan dalam hakikat Makemit itu sendiri, yakni untuk menyucikan diri lahir batin dalam rangka mementaskan 
tarian sakral Barong Brutuk.

2. Santosa, yang artinya puas terhadap apa yang telah dimiliki, dalam artian tidak dengki dengan kepunyaan orang lain. Konsep ini direfleksikan dalam perlakuan yang setara sama rata dan sama rasa, dalam artian tidak ada Teruna yang diistimewakan dalam proses Makemit tersebut. Hidup mandiri dan apa adanya bertujuan belajar mensyukuri apa yang ada dan disediakan.

3. Tapa, yang artinya tahan terhadap ujian dan segala macam gangguan, dimana hal ini direfleksikan melalui seperangkat aturan dan pantangan yang harus ditaati dalam upaya memperoleh kesucian.

4. Swadhyaya, yang artinya tekun mempelajari pengetahuan kerohanian. Hal ini telah diaplikasikan dalam kegiatan tapa, brata, yoga, dan samadhi yang dilakukan secara rutin, sebagai proses perenungan memahami hakikat dan eksistensi Ida Sang Hyang Widhi Wasa. Dalam prosesnya tidak jarang menerima petunjuk dari pemuka-pemuka agama (Pamangku) setempat.

5. Iswarapranidhana, yang artinya tekun memuja Ida Sang Hyang Widhi Wasa, dimana hal ini telah dilaksanakan melalui persembahyangan rutin setiap hari selama Makemit, beserta ritual-ritual yang pada hakikatnya merupakan pemusatan pikiran hanya tertuju pada Beliau.

\subsubsection{Asana}

Asana merupakan sikap atau posisi tubuh yang teguh, kuat, dan nyaman dilakukan ketika melakukan meditasi (Brahman, 2017:17). Konsep ini telah dipraktikkan saat para Teruna melaksanakan aktivitas tapa, brata, yoga, dan samadhi yang dilakukan secara rutin.

\subsubsection{Pranayama}

Pranayama merupakan teknik pengaturan prana atau energi yang terdapat dalam diri manusia, umumnya dilakukan dengan pengaturan nafas. Konsep ini telah dipraktikkan saat para Teruna melaksanakan aktivitas tapa, brata, yoga, dan samadhi yang dilakukan secara rutin, bersamaan dengan aktivitas asana yang telah dilakukan.

\subsubsection{Pratyahara}

Pratyahara adalah bagian dari pendisiplinan diri dalam yoga untuk mengendalikan indria. Pratyahara merupakan penarikan indriya dari objek-objek yang dapat menimbulkan rangsangan atau goncangan pada batin. Implementasi esensi dari konsep ini direfleksikan melalui segala aturan dan pantangan yang berlaku selama proses Makemit. Puncaknya dapat dilihat saat prosesi pengambilan Tirtha Kayan Teruna yang dilakukan dengan penuh kesakralan dan tanpa busana yang melambangkan penarikan dari segala macam kemelekatan dan godaan indriya.

\subsubsection{Dharana}

Dharana merupakan pemfokusan pikiran pada satu objek meditasi. Dalam hal ini, pikiran para Teruna yang mengikuti seluruh prosesi Makemit diarahkan terus-menerus kepada Ida Sang Hyang Widhi Wasa beserta manifestasiNya sebagai dewa-dewa dalam terminologi lokal Desa Terunyan. Hal ini bertujuan menjadikan diri sebagai niyasa, yakni memiliki kelayakan dalam aspek kesucian untuk mencapai penyatuan jiwa raga dengan kekuatan suci Beliau.

\subsubsection{Dhyana}

Dhyana merupakan arus pikiran yang terus menerus merenungkan objek yang dimeditasikan. Implementasi dari esensi dari konsep ini dilakukan melalui penghayatan akan eksistensi Ida Sang Hyang Widhi Wasa, beserta manifestasi-Nya sebagai dewa-dewa dalam terminologi lokal Desa 
Terunyan, serta ideologi utama dari pementasan Barong Brutuk, yakni memohon kesuburan demi kemakmuran Desa Terunyan.

\subsubsection{Samadhi}

Samadhi merupakan bagian terakhir dari Astangga Yoga. Brahman (2017:17) menyatakan bahwa Samadhi merupakan titik puncak dari pelaksanaan meditasi. Seorang yogi yang mengalami alam Samadhi telah mencapai penyatuan dengan objek yang dimeditasikan. Antara si subjek dan objek yang dimeditasikan telah mencapi penyatuan. Dalam konsep ini, para Teruna yang telah berhasil menarikan Barong Brutuk tanpa hambatan telah mengalami penyatuan dengan tokoh-tokoh dewa yang diperankan. Sebagaimana yang telah diuraikan pada pembahasan sebelumnya bahwa para Teruna merasakan jiwa raganya menyatu dengan kekuatan suci para dewa yang diperankan, bukan pengambilalihan raga. Hal ini menandakan keberhasilannya dalam mencapai niyasa dalam terminologi konsep lokal setempat.

Beranjak dari korelasi antara konsep Astangga Yoga yang dikemukakan oleh Rsi Patanjali tersebut dengan praktik Makemit sebagai rangkaian dari pementasan Barong Brutuk, maka terlihat jelas bahwa keduanya sangat relevan. Dalam balutan terminologi kearifan lokal khas Terunyan yang paling ikonik, yakni Barong Brutuk, prosesi Makemit sebagai prasyarat dalam mementaskannya merupakan praktik esensial dari Raja Yoga yang sejati. Hal ini penting untuk diaplikasikan secara bergenerasi dan berkesinambungan guna menciptakan generasigenerasi muda yang berkualitas, berkarakter dan berjiwa religius, baik dalam lingkup Desa Terunyan khususnya, dan dapat digali pula polapola yang serupa dalam lingkup tradisi lokal Hindu masyarakat Bali pada umumnya.

\section{PENUTUP}

Menyimak pembahasan di atas, maka sebagai penutup dapat disimpulkan bahwa praktik Makemit sebagai rangkaian dari persiapan pementasan tarian sakral Barong Brutuk memiliki esensi yang sama dengan konsep dan tujuan Raja Yoga. Praktik ini merupakan konsep yang diwariskan oleh pemikiran para leluhur masyarakat Desa Terunyan pada masa yang lampau tentang pola-pola pengimplementasian religiusitas dan pembentukan karakter bagi generasi mudanya. Secara hakikat, sesungguhnya praktik Makemit menurut terminologi masyarakat Desa Terunyan adalah praktik Raja Yoga yang sejati apabila dilihat dari esensinya. Indikator keberhasilannya adalah dilihat dari keberhasilan para Teruna dalam menarikan Barong Brutuk, dimana menurut keyakinan masyarakat setempat, apabila tidak dirasakan adanya panas, lemas, bahkan pingsan serta tidak adanya keinginan untuk buang air kecil maupun besar yang dapat menghalangi pementasan tersebut. Hal ini sangat sesuai dengan pernyataan dari Svetasvatara Upanisad I.13 mengenai indikator keberhasilan dari yoga. Sudah menjadi kewajiban bagi generasi muda untuk senantiasa mengeksplorasi kearifan-kearifan lokal yang banyak terdapat dalam kehidupan masyarakat beragama. Disamping untuk memahami konsep esensinya, sekaligus yang terpenting adalah menghayati dan mengimplementasikannya untuk perbaikan kualitas karakter religius di masa-masa mendatang.

\section{DAFTAR PUSTAKA}

Brahman, I Made Adi. "Korelasi Ajaran Cadu Sakti Dengan Catur Yoga", dalam Jurnal Vidya Samhita, Volume III, No. 2, 2017, Institut Hindu Dharma Negeri Denpasar.

Danandjaja, James. 1980. Kebudayaan Petani Desa Trunyan di Bali. Jakarta: Dunia Pustaka Jaya.

Jayendra, Putu Sabda. 2018. "Sasolahan Barong Brutuk di Desa Terunyan, Kecamatan Kintamani, Kabupaten Bangli: Suatu Kajian Etnopedagogik”. Disertasi Program 
Pascasarjana Institut Hindu Dharma Negeri Denpasar.

Kinasih, Arum Sukma. 2010. "Pengaruh Latihan Yoga Terhadap Peningkatan Kualitas Hidup", dalam Jurnal Buletin Psikologi, Volume 18, No. 1, 2010, Fakultas Psikologi Universitas Gadjah Mada Yogyakarta.

Maswinara, I Wayan. 1997. Bhagawadgita. Surabaya: Paramita.

Pudja, G dan Tjokorda Rai Sudharta. 2004. Manawadharmasastra. Surabaya: Paramita.

Radhakrishnan, S. 2008. Upanisad-upanisad Utama. Surabaya: Paramita.

Radhakrishnan, S. 2010. Bhagawadgita. Yogyakarta: IRCiSoD.

Tim Penyusun. 2006. Kamus Istilah Agama Hindu. Denpasar: Pemerintah Provinsi Bali.

Titib, I Made. 1996. Veda Sabda Suci Pedoman Praktis Kehidupan. Surabaya: Paramita. 